\title{
Perception and Barrier on Using Zoom in Speaking Class During COVID-19 Pandemic
}

\author{
Sebastianus Menggo \\ Universitas Katolik Indonesia Santu Paulus Ruteng, Indonesia \\ \{sebastian.pradana@gmail.com\}
}

\begin{abstract}
Zoom application is an excellent choice during the COVID-19 Pandemic. It promotes a more attractive, contextual web camera and microphone to interact in real-time as happens in a traditional class or face-to-face setting. This research explores and reveals the students' perception of using Zoom in speaking class during the COVID-19 Pandemic. This study surveyed 96 students of English Study Program of Universitas Katolik Indonesia Santu Paulus Ruteng, Indonesia. The questionnaire was used to gather data, which was then quantitatively and qualitatively analyzed. According to the findings, students' perception of using Zoom in speaking class during the COVID-19 Pandemic was primarily included in positive perception. Moreover, the barriers found were institutional ICT infrastructure, $63.6 \%$, internet network stability, $98 \%$, availability of internet quota package, 98\%, and the student's lack of initiative, 86.4\%. According to the results, university students had a positive perception of using Zoom; however, there were several obstacles that hampered the application's execution.
\end{abstract}

Keywords: ICT literacy, perception, speaking class, teaching, Zoom application

\section{Introduction}

Today's pupils in a learning process face unavoidable and urgent demands for ICT skills. A strong ICT competency motivates students to fulfil numerous university assignments and be prepared to compete for many job opportunities that always require these ICT skills. These requirements imply that students continue to upgrade their ICT skills in line with the development and advancement of ICT itself. ICT competence is demonstrated by a person's ability to use, modify, or create a variety of software applications that enable a great amount of attention to and win numerous work possibilities [1],[2]. The advancement and development of various digital technologies have impacted numerous aspects of life, including education. Therefore, the availability of adequate ICT infrastructure is the right choice and decision for educational institutions to provide great learning services to students and other stakeholders during the COVID-19 Pandemic [3],[4].

Educational institutions' availability of ICT infrastructure, systems, and management cannot be ignored during the COVID-19 or post COVID-19 pandemics, as they directly impact how learning is implemented. With the availability of ICT infrastructure, conventional classes can be replaced by digital classroom sessions that are more effective in terms of (time), efficiency (cost), learning autonomy, active involvement, and broader access (followed by thousands of students without being limited by space, such as face-to-face classes) [5],[6]. 
Additionally, the availability of ICT systems and management is a variable that is inversely related to the availability of ICT infrastructure. Human resources are required to develop an ICT system and management by an educational institution to provide adequate learning services to students and avoid the university's bankruptcy due to the impact of the COVID-19 [7],[8]. This phenomenon has been experienced by all educational institutions worldwide, including the Universitas Katolik Indonesia Santu Paulus Ruteng, Flores, which has prepared infrastructure, systems, and online learning management for all learning processes using the MOODLE Learning Management System since the even semester of the academic year 2019/2020. The implementation of the lecture system was motivated by the spread of the Covid-19, which did not allow face-to-face lectures to be carried out.

The spread of the Covid-19, which continues to increase from time to time, is not an obstacle to educational services stagnation, but rather space for all stakeholders to reflect on how to continue to foster students' ICT competence, the availability of ICT infrastructure by the government, and the display of digital services in all areas of public service. Indeed, ICT-based learning demonstrates the quality process, whether in terms of teaching method innovation, student learning autonomy, media, and evaluations that positively affect student learning outcomes [9],[10]. These researchers emphasized that ICT competence plays an essential role in transforming knowledge, presenting the value of initiative, creativity, and independence of students in meeting the expected learning targets.

The presence of the COVID-19 had an impact on different educational services before the emergence of this virus. According to the Ministry of Education, Culture, Research, and Technology, there are 407,000 schools in Indonesia with inadequate learning services due to the COVID-19's impact, as well as 3.4 million teachers and 56 million pupils [11]. According to this data, the Indonesian government does not want the educational process to stagnate during COVID-19. It is committed to ensuring that students' rights to educational services are fulfilled. To ensure this, through the Ministry of Education, Culture, Research and Technology, the Government of Indonesia ratified a policy of implementing learning from home.

Learning from home is implemented with two approaches: the distance learning approach in the network (online) and outside the network (offline). The distance learning approach method in the network (online) in learning from home is still not optimal. This idea happens because of the lack of distance learning media applications in the appropriate network that have not been integrated with each other. The implementation of learning from home could not provide optimal results. Based on this argument, various applications that support the success of the online learning process, such as WhatsApp, Google Meet, Google Classroom, Edmodo, Schoology, WebEx, Moodle, Ruang Guru, Canvas, and many more, are legitimately used [12].

The reality is that when a number of these applications are implemented, they meet a number of problems, including a limited number of features, impractical and expensive use, and some of them waste internet quota, all of which contribute to a number of applications having a limited impact on meeting learning needs during the COVID-19 period [13],[14]. On the other hand, the efficacy of employing learning media applications in the learning process can be attained if they are practical for students to use, conserve internet quota, and are affordable. These problems can be overcome by using the Zoom application as a learning medium, including speaking classes.

The Zoom application is very easy to use with internet quota savings. Zoom is equipped with features, such as audio and video conference (private and group), audio call, audio and visual call (private and group), chat box (private and group), share screen, tutor box, audio and video recorder, and many more [15],[16]. Some of these features are owned by the Google Meet 
and WebEx applications. However, these two applications consume more internet quota when compared to the Zoom application and are not practical to use as the Zoom application.

This situation is certainly not beneficial for all education stakeholders. The online learning applications, including Zoom, are merely media in conveying knowledge that cannot be avoided from their advantages and disadvantages. It is realized that any learning application media used during the COVID-19 Pandemic cannot be separated from its advantages and disadvantages [17],[18]. Educators are required to be able to determine and choose online learning application media that help achieve student learning targets and affect their positive perceptions in maintaining or even increasing students' learning enthusiasm. Perceptions, both positive and negative, are influenced by the application of a learning media. Educators must be aware of students' perceptions of the application of one of the learning components since the results of these perceptions serve as reflection material for educators to update their media, techniques, assessments, and other learning components choices [19],[20].

Previous studies evidence that the Zoom application is an online learning application that can help students interact directly with the teacher has a web camera and microphone to interact in real-time, as happens in traditional or face-to-face classes, creates a main room and breakout rooms that can accommodate up to 1000 participants, teachers can directly observe the active participation of students, unlimited host and co-host arrangements, share various learning documents, and are practically used by both teachers and students [21],[22]. In addition, with the application of the Zoom application, teachers and students are given a choice of free Zoom with a duration of 40 minutes and paid Zoom for unlimited use at a relatively low cost, helping to form a disciplined value by encouraging students to join on time, responsibility value by asking students present all coursework virtually, as well as a space for forming an initiative and creativity values in improving ICT competence itself [15],[23].

Unfortunately, scientific investigations could not provide significant support for examining research findings regarding student perceptions and the challenges associated with employing the Zoom application in speaking classes during the COVID-19 Pandemic. Thus, the purpose of this study is to fill in the research gap by examining students' perceptions and challenges to using Zoom in speaking classes during the COVID-19 era.

Previous studies have provided evidence that the Zoom application could influence students' perception of learning English during the COVID-19 Pandemic [24],[25]. The features available in the Zoom application can facilitate the various needs of students' speaking subject demands. The Zoom application has several features, such as audio, audiovisual, and video conferencing (private and group), and many more, where these features can encourage students' enthusiasm and fighting spirit in meeting the expected competency targets in speaking courses [26],[27]. The video conferencing feature (private and group) enables professors to communicate directly with students and monitor important evaluation aspects of speaking courses, such as word choice, pronunciation accuracy, grammar, comprehension, fluency, and intonation accuracy. As proven by organizations that have already entered the Fortune 500, this Zoom application is believed to be of high quality in supporting the learning process throughout the COVID-19 Pandemic [28].

The data and descriptions above inspire the researcher to propose the following two research questions:

1. How are students' perceptions of using the Zoom application in speaking courses during the COVID-19 Pandemic?

2. What are the challenges for using the Zoom application in speaking courses during the COVID-19 Pandemic? 
Based on these two questions, the purpose of this study is to reveal scientific data related to the students' perceptions and the factors that hinder using the Zoom application in speaking courses during the COVID-19 Pandemic.

\section{Review of Literature \\ ICT competence in speaking class}

Today, communication and information technology (ICT) development and advancement are integrally linked to human life. ICT has an impact on the application of a variety of advancements in a learning activity, including teacher teaching strategies, student learning strategies, media, and assessments, all of which contribute to the achievement of student learning outcomes [29]. Based on this argument, students must have ICT competence in order to be able to take advantage of various business opportunities that rely on ICT literacy. ICT competence comes from understanding digital competence. Digital competence consists of three main components: information competence, media literacy, and information and communication technology competence [29-31]. These three components of digital competence are basic needs for students in increasing the efficiency and effectiveness of their learning. In the context of this research, digital competence focuses on information and communication technology competence.

An individual's information and communication technology competency is defined as their ability to analyse digital information media, determine the types of applications available in digital media, and produce relevant media or applications to support learning outcomes [33]. ICT competence proposed by [33] strongly indicates that students are highly suggested to understand, modify, or create some relevant applications in learning English, including speaking courses. Some relevant applications, such as WhatsApp, Zoom, Google Meet, Google Classroom, Edmodo, Schoology, WebEx, Moodle, Ruang Guru, and Canvas, are required for speaking courses because a variety of features in these applications can assist students in identifying shortcomings and weaknesses in speaking skill assessments [33-35].

Indeed, speaking skill is absolutely mastered by English learners, besides listening, reading, writing skills and the three components in English, such as vocabulary, grammar and pronunciation [36],[37]. These researchers further affirmed that four English language skills and three English language components are inter-dependence in language use. In measuring speaking ability and assessment is required, and it plays a vital role in the English speaking learning process. The assessment makes both teacher and student aware of the expected learning outcomes in the teaching process. The lecturer is advised to provide a speaking evaluation consisting of the speaking aspects, indicators, weights, scores, and descriptors of the existing scores. A variety of components must be included in this speaking evaluation aspects, such as understanding the topic, proper use of grammar, accurate pronunciation, fluency, and appropriate word choices [30],[38].

\section{The Zoom application use and its challenges in speaking class}

The shift in learning paradigms from offline settings or face-to-face meetings to digital platforms during the COVID-19 Pandemic has had an effect on the service system and the mindset of teachers and students engaged in learning activities. Online learning platforms encourage ICT competence as an absolute necessity for education stakeholders due to a number of benefits from information and communication technology in the learning process, such as (1) as a source of knowledge, (2) as an effective learning medium for assessing achievement of desired competency standards, (3) as a control medium for learning administration systems, and (4) tools to assess student progress [7],[10]. The benefits of ICT competence have an impact on 
students' perceptions of educational services during the COVID-19 Pandemic, including speaking courses at the English education study program, Universitas Katolik Indonesia Santu Paulus Ruteng.

This speaking course consists of three types, namely speaking for daily communication, speaking for debate and argumentation, and speaking for academic purposes. The perception questionnaire was administered to only students (respondents) who had previously programmed speaking for debate and argumentation, as well as speaking for academic purposes. Educators need to understand student perception as it has an effect on enhancing motivation and improving students' study habits [40].

One of the orientations of ICT competence in English learning during the COVID-19 Pandemic is the ability to create or use a variety of relevant applications to aid in the development of speaking competence, such as Zoom, WhatsApp, Google Meet, Google Classroom, Edmodo, Schoology, WebEx, Ruang Guru, Canvas and many more. The Zoom application is the subject of this article due to the researcher's real-world experience serving learning during the COVID-19 period. In addition, the Zoom application is also easy to use for distance education learning media ranging from elementary, secondary, to tertiary education for all types of courses [21], [41].

This Zoom application is easy to use on various digital devices, such as Smartphones (Android and IOS-based), Personal Computer (PC), Laptops, Notebooks, and Tablets with internet quota savings, provides features, audio and video conferencing (private and group), audio calls, audio and visual calls (private and group), chat boxes (private and group), share screens, tutor boxes, non-verbal interactions, and audio and video recorders that can encourage the learning process during the Covid-19 Pandemic and facilitate students and educators during the learning process [16],[27]. Teachers and students can be assisted; various Zoom capabilities can be combined with other primary and secondary learning media applications. The primary education media applications intended are developed and prepared by teachers using Microsoft Office, Microsoft PowerPoint, Focus Sky, and Prezi. Meanwhile, secondary learning media applications are additional learning tools that support the teaching and learning process, such as Cake, Ruang Guru, and Quipper.

The advantages offered by the Zoom application do not mean that it does not have weaknesses, which are challenge for its application during the COVID-19 Pandemic. The weaknesses encountered from online learning during the COVID-19 Pandemic [14],[41] are (1) (1) availability of digital media from teachers, students, and parents; (2) low digital literacy competence among parents and students; (3) low motivation of students to explore knowledge information via a variety of digital media; (4) the stability of the internet network, which constantly interferes with the process of downloading data when accessing the internet; (5) the students' eyes health; (6) funding for internet subscriptions or buying data quotas; (7) identifying information knowledge on the internet that has not been integrated into learning needs; and (8) pupils' lack social competency when interacting with others

\section{Research Methods}

This study used a survey design. It took place in June 2021 at the English study program, Universitas Katolik Indonesia Santu Paulus Ruteng. This design's primary purpose is to identify community requirements for educational services in terms of programs, courses, school facility improvements, and involvement in school or community planning [43]. In the context of this 
research, this design was chosen to change the choice of learning applications or add features in the Zoom application to support the educational service process in speaking courses during the COVID-19 Pandemic.

\subsection{Population and Sample}

The research population was 347 students from 13 classes at different levels of the English Study Program. Ninety-six students were selected as a sample by using a multistage cluster random sampling technique. These respondents are limited to students enrolled in the English language education program at Universitas Katolik Indonesia Santu Paulus Ruteng, who take speaking for debate and argumentation and speaking for academic purposes courses.

\subsection{Instrument}

The questionnaire of a four-point Likert scale was used to collect data. The questionnaire covered students' perceptions and challenges of the Zoom application use in speaking courses during the COVID-19 Pandemic. Eighteen items were made up of closed-ended questions, which consisted of four options. Students were asked to choose one of the four options provided. The questionnaire was distributed in Google form.

\subsection{Data Analysis}

From the questionnaire, numerical computations were performed in order to obtain the percentage. After conducting a quantitative analysis with the excel chart data series software program, the researcher used qualitative interpretation to finalize the interpretation.

\section{Results and Discussion}

This section focuses on data findings related to inhibiting factors and student perceptions of the Zoom application use in speaking courses during the COVID-19 Pandemic. Both data are described in detail in Table 1 below.

Table 1. Students' perception and factors hinder the Zoom application use in speaking course

\begin{tabular}{clrccc}
\hline No & \multicolumn{1}{c}{ Statements } & \multicolumn{3}{c}{ Answer option } \\
\cline { 3 - 5 } & \multicolumn{1}{c}{ SA } & $\mathrm{A}$ & $\mathrm{D}$ & $\mathrm{SD}$ \\
\hline 1 & $\begin{array}{l}\text { I like and enjoy practicing English speaking } \\
\text { through the Zoom application }\end{array}$ & $52.1 \%$ & $26 \%$ & $11.5 \%$ & $10.4 \%$ \\
\hline 2 & $\begin{array}{l}\text { Zoom application use helps me to reduce my } \\
\text { speaking anxiety }\end{array}$ & $48.9 \%$ & $34.4 \%$ & $10.4 \%$ & $6.3 \%$ \\
\hline 3 & $\begin{array}{l}\text { Zoom application improves my English } \\
\text { pronunciation accuracy }\end{array}$ & $31.2 \%$ & $35.5 \%$ & $20.8 \%$ & $12.5 \%$ \\
\hline 4 & $\begin{array}{l}\text { Zoom application improves my English } \\
\text { grammar }\end{array}$ & $26.4 \%$ & $39.6 \%$ & $22.9 \%$ & $11.1 \%$ \\
\hline 5 & $\begin{array}{l}\text { Zoom application improves my English } \\
\text { vocabulary }\end{array}$ & $34.4 \%$ & $38.5 \%$ & $15.6 \%$ & $11.5 \%$ \\
\hline 6 & Zoom application improves my English fluency & $52.1 \%$ & $26 \%$ & $11.5 \%$ & $10.4 \%$ \\
\hline 7 & $\begin{array}{l}\text { Zoom application improves my English } \\
\text { comprehension }\end{array}$ & $52.1 \%$ & $26 \%$ & $11.5 \%$ & $10.4 \%$ \\
& & & & \\
\hline
\end{tabular}




\begin{tabular}{clcccc}
\hline 8 & $\begin{array}{l}\text { Zoom application improves my non-verbal } \\
\text { communication use (body language) in } \\
\text { speaking class }\end{array}$ & $48.9 \%$ & $37.5 \%$ & $8.4 \%$ & $5.2 \%$ \\
\hline 9 & $\begin{array}{l}\text { Zoom is effective learning media to use my } \\
\text { time efficiently and practicing English } \\
\text { independently at home }\end{array}$ & $46.8 \%$ & $39.6 \%$ & $8.4 \%$ & $5.2 \%$ \\
\hline 10 & $\begin{array}{l}\text { Zoom application helps me to have a self- } \\
\text { assessment on English speaking }\end{array}$ & $53.1 \%$ & $34.4 \%$ & $6.3 \%$ & $7.2 \%$ \\
\hline 11 & $\begin{array}{l}\text { Zoom application use changes my learning } \\
\text { habit on speaking course }\end{array}$ & $43 \%$ & $35.2 \%$ & $13.5 \%$ & $8.3 \%$ \\
\hline 12 & $\begin{array}{l}\text { Zoom is an appropriate application to control } \\
\text { my active participation during speaking class }\end{array}$ & $53.1 \%$ & $34.4 \%$ & $6.3 \%$ & $7.2 \%$ \\
\hline 13 & $\begin{array}{l}\text { I Found difficulty in using some features on the } \\
\text { Zoom application }\end{array}$ & $6.3 \%$ & $12.5 \%$ & $42.7 \%$ & $38.5 \%$ \\
\hline 14 & $\begin{array}{l}\text { The stability of the fast internet connection } \\
\text { makes my online speaking class running well }\end{array}$ & $56.3 \%$ & $41.7 \%$ & $2 \%$ & - \\
\hline 15 & $\begin{array}{l}\text { Digital ownership devices help me to take } \\
\text { online speaking classes }\end{array}$ & $43.8 \%$ & $46.8 \%$ & $7.2 \%$ & $3.1 \%$ \\
\hline 16 & $\begin{array}{l}\text { I have a financial problem in purchasing } \\
\text { internet data to download big files and } \\
\text { participate in video conferences during } \\
\text { speaking class }\end{array}$ & $56.3 \%$ & $41.7 \%$ & $1 \%$ & $1 \%$ \\
\hline 17 & $\begin{array}{l}\text { The availability of campus ICT infrastructure } \\
\text { hinders my online speaking class }\end{array}$ & $42.8 \%$ & $20.8 \%$ & $22.9 \%$ & $13.5 \%$ \\
\hline 18 & $\begin{array}{l}\text { The student's lack of initiative hinders my } \\
\text { online speaking class }\end{array}$ & $37.5 \%$ & $48.9 \%$ & $9.4 \%$ & $4.2 \%$ \\
\hline Sour & & & & \\
\hline
\end{tabular}

Source: Researcher's data

\section{Note: $\mathbf{S A}=$ Strongly Agree, $A$ = Agree, $\mathrm{D}=$ Disagree, $\mathrm{SD}=$ Strongly Disagree}

The 18 statements in Table 1 above are classified into several components, namely statements related to student psychological factors on the application of the Zoom application in the learning process of speaking courses (statements number 1 and 2), statements related to aspects of evaluating speaking skills (statements 3 - 8), student responses related to independence in practising English speaking, personal reflection, changes in study habits, and activeness in the process (statements 9-12), the ability to use features in the Zoom application (statement number 13), and inhibiting factors in online learning (statements 14-18).

\section{Discussion}

\section{Positive Perception of Zoom application use in speaking course}

Table 1 in statement 1 indicates that most respondents $(\mathrm{SA}=52.1 \%$ and $\mathrm{A}=26 \%)$ have a positive perception of using the Zoom application in practising their English speaking. Statement number 1 is also strongly intertwined from the answers Disagree $(11.5 \%)$ and Strongly Disagree $(10.4 \%)$. However, most respondents dominantly perceived that the use of the Zoom application is helpful in practising their English speaking ( $\mathrm{SA}+\mathrm{A}=78.1 \%$ ). Positive responses also occur in statement number 2, which indicates that the Zoom application can reduce their anxiety in speaking $(\mathrm{SA}=48.9 \%$ and $\mathrm{A}=34.4 \%=83.3 \%)$.

While the percentage of the Disagree reached $10.4 \%$ and Strongly Disagreed 6.3\%. Positive responses to statements number 1 and 2 indicate that the Zoom application touches the psychological components of students (liking and reducing anxiety). This psychological 
component plays an important role in ensuring students' academic achievement [43-44]. Students are delighted and love practising their English speaking skills when the Zoom application is used during the COVID-19 Pandemic. In addition, applying the Zoom application, students do not feel anxious about speaking in front of the class, as they do in conventional classes. Speaking anxiety is a variable that lecturers must anticipate, as it has a negative impact on speaking performance itself [45-47]. When anxiety arises, the performance of students speaking to speak in English is not optimal expected.

The percentage of positive responses is also found in statements number $3-7$ (see Table 1 above), which is a statement to cover a number of aspects of evaluation in speaking skills. Positive responses were found in statement number 3, namely $66.7 \%$ (Strongly Disagree $=$ $31.2 \%$ and Agree $=35.5 \%$ ). Option of Disagree $=20.8 \%$ and Strongly Disagree $=12.5 \%$. The dominance of positive responses is also found in the answer options in statements number 4 7. The dominance of this positive response shows that the application of the Zoom application in speaking courses can fulfil the evaluation aspects of speaking skills itself. These aspects of evaluation are reciprocal, such as comprehension, the accuracy of pronunciation, grammar, vocabulary choice, and fluency [39].

In addition, the positive response to the Zoom application was expressed by the answer options in statement number 8 . The dominance of positive responses reached $86.4 \%$, namely Strongly Agree $=48.9 \%$ and Agree $=37.5 \%$. On the other hand, the negative response was $13.6 \%$ (Disagree $=8.4 \%$ and Strongly Disagree $=5.2 \%$ ). It is interesting for the dominance of positive responses to this statement as the Zoom application encourages students to use nonverbal communication (the use of body language) in conveying meaning in conversation. By utilizing the audiovisual call feature, lecturers can observe directly how non-verbal communication is used to communicate with students during their speaking practice. Students' use of non-verbal communication enables lecturers to measure the originality of students' comprehension of a given topic [48], [49].

Positive perceptions were also found in the answer option for statement number 9 regarding student autonomy to practice in English. Respondents responded with Strongly Agree, 46.8\% and Agree, $39.6 \%$, so that the percentage of approval of the application of Zoom encouraging students to practice independently reached $86.4 \%$. Positive ratings were also found in statement number 10 , reaching $87.5 \%(\mathrm{SG}=53.1 \%+\mathrm{A}=34.4 \%)$. The dominance of positive responses was also expressed from statements 11 and 12 (see Table 1).

Indeed, the respondents agreed that the Zoom application, with its various features, could help student independence, self-evaluation, learning habits (from offline becomes online habits), and support students to be actively engaged during speaking class. Learning habits contribute toward students learning achievement [50],[51]. Changes in study habits have an impact on aspects of learning autonomy, reflection on learning progress, and active participation in Zoom meetings according to the schedule provided.

The percentage of negative responses was found to be $81.2 \%$ in statement number 12 , with disagreement reaching $42.7 \%$ and strongly disagree reaching $38.5 \%$. However, this is a negative statement with a positive meaning, referring to the respondents' difficulty operating a number of Zoom application features while participating in the speaking course. The Zoom application also has an effect on psychological factors, including the respondents' anxiety. This statement shows a positive response up to $83.3 \%(\mathrm{SA}=48.9 \%+\mathrm{A}=34.4 \%)$. Statements $14-$ 18 (see Table 1 above) indicate a number of challenges for online learning.

\section{The Challenges of Zoom application use}


The Zoom application is only one of the alternative learning media in the COVID-19 pandemic situation, which cannot be avoided from its advantages and disadvantages [14],[41]. The dominance of positive responses to statements number 1-12 in this research questionnaire is an advantage of the Zoom application with the various features. However, a negative response was found in this study, which is a challenge for online learning during the COVID-19 Pandemic. Challenges from students themselves include an initiative value and the ability to operate several features of the Zoom application. Statement number 13 shows that $81.2 \%$ (Strongly Disagree $=38.5 \%+$ Disagree $=42.7 \%$ ) students do not agree that they find difficulties in using a number of features in the Zoom application. However, the opposite is shown from statement number 18, which indicates that $86.4 \%$ (Strongly Agree $=37.5 \%+$ Agree $=48.9 \%$ ) students have low initiative value in upgrading speaking achievement. This result confirms that the student's lack of initiative is one of the challenges in online learning.

The second factor that becomes problematic in online learning is the stability of the internet connection. This result is supported by the student's response to the answer options from statement number 14, which shows 98\% (Strongly Agree 56.3\% + Agree 41.7\%) students agree that the problem of instability in internet access is a barrier factor in online learning. The percentage of digital device ownership is also a third factor that becomes a challenge in online learning. This is indicated by the percentage of data analysis results in statement number 15 , which reached $90.6 \%$ ( $\mathrm{SA}=43.8 \%+\mathrm{A}=46.8 \%)$. The researcher's experience reinforces this result during the lecture process that most students already have digital devices in participating in the online lecture process. The challenges found in this research can be different in other places or at other levels of education. In the context of this research, ownership of digital devices is not a challenge.

Another obstacle to online learning is the financial aspect. Finances are required to purchase internet data packages necessary for downloading and participating in various video conferences during the learning process. This statement is supported by data from the answer options for statement number 16, where the percentage of financial agreement is an inhibiting factor in online learning, reaching $98 \%(\mathrm{SA}=56.3 \%+\mathrm{A}=41.7 \%)$. This percentage of agreement is supported by the researcher's experience in teaching speaking courses. Due to insufficient data packages, the majority of the students were unable to join Zoom until they finish speaking lecturing. The third barrier to online learning is a lack of institutional ICT infrastructure. The data in statement number 17 indicates that $63.6 \%(\mathrm{SA}=42.8 \%+\mathrm{A}=20.8 \%)$ of students agree that the availability of institutional ICT infrastructure is an immediate challenge for stakeholders.

This is reinforced by [5],[8], who emphasizes that the availability of ICT infrastructure from an institution is very important to avoid stagnation of educational services. Indeed, the Universitas Katolik Indonesia Santu Paulus Ruteng, Flores, has prepared infrastructure, systems and online learning management with the MOODLE Learning Management System for all learning processes, but due to the low student initiative and an unstable internet connection, the percentage of agreement that the availability of institutional ICT infrastructure is one of the inhibiting factors for online learning during the COVID-19 Pandemic. The data in this study revealed four factors that contribute to the challenge of online learning: internet connection stability, budget restrictions, institutional ICT infrastructure availability, and student initiation.

This study focuses on answering two research questions, namely understanding the university students' perceptions regarding the application of the Zoom application and the challenges of implementing this application. The university students (respondents) mostly have a positive perception toward the implementation of this application. The conclusion of this 
perception is positive energy for the university students to practice speaking English independently based on digital applications, including the Zoom application.

This conclusion also encourages speaking instructors to continue using particular application media in the learning process. Speaking instructors can explore the advantages and disadvantages of each Zoom application feature and encourage students for using certain Zoom application features as a medium for university students to practice speaking autonomously. With this personal speaking exercise, students may analyze a variety of evaluation components in speaking, such as pronunciation correctness, grammar, vocabulary, and fluency, and create an appropriate strategy to overcome evaluation components that do not match the standards.

What is interesting about the research data is that the majority of respondents have positive perceptions, despite the fact that a number of obstacles to implementation are found, such as internet connection stability, limited budget, institutional ICT infrastructure availability, and student low initiative value. In relation to these four challenges, stakeholders, primarily the government, student parents, universities, and students themselves, are advised to adjust to these obstacles. For example, students are encouraged to take more initiative, the government is encouraged to continue building infrastructure for stable internet connections, parents are encouraged to budget a special budget for data packages during learning in the Pandemic, and universities are encouraged to prepare and manage ICT systems in strengthening teachinglearning process.

\section{Conclusion}

Students in an online learning platform must possess ICT competencies. One of these ICT competencies is the ability to operate the Zoom application. This application assists students in developing their learning autonomy and English-speaking proficiency. This argument is shown by the positive perception of the respondents on the application of the Zoom application in the speaking class. Additionally, the data in this study demonstrate four elements that become barriers to online learning during the COVID-19 Pandemic: internet connection stability, finances, institutional ICT infrastructure availability, and student's lack of initiative. These four obstacles were solved immediately by stakeholders in order to avoid impeding the advancement of students' ICT competencies and perceptions of the use of digital applications during the Pandemic.

\section{References}

[1] C. K. Gomathy, "A study on the effect of awareness and education on digital literacy," Int. J. Sci. Res. Rev., vol. 7, no. 3, pp. 51-57, 2018.

[2] A. Suherman, T. Supriyadi, and I. Safari, "Promoting digital literacy skills: An action research to people of Kampung Literasi," Univers. J. Educ. Res., vol. 8, no. 4, pp. 1372-1386, 2020.

[3] J. Usman, "Pengelolaan infrastruktur teknologi informasi dan komunikasi dalam mendukung kinerja layanan pendidikan di Sekolah Tinggi Agama Islam Negeri (STAIN) Pamekasan,” J. Anal. Sist. Pendidik. Tinggi, vol. 1, no. 2, pp. 79-92, 2017.

[4] H. Elmunsyah, "A Study of ICT infrastructure and access to educational information in the outskirts of Malang.," Acta Didact. Napocensia, vol. 5, no. 2, pp. 41-48, 2012.

[5] D. Çakici, "The use of ICT in teaching English as a foreign language," Particip. Educ. Res., vol. Special Is, no. 4, pp. 73-77, 2016. 
[6] S. Sukmawati and N. Nensia, "The role of Google classroom in ELT," Int. J. Educ. Vocat. Stud., vol. 1, no. 2, pp. 142-145, 2019.

[7] A. Adisel and A. G. Prananosa, "Penggunaan teknologi informasi dan komunikasi dalam sistem manajemen pembelajaran pada masa pandemi COVID-19," ALIGNMENT J. Adm. Educ. Manag., vol. 3, no. 1, pp. 1-10, 2020.

[8] D. Herdiana, R. Rudiana, and S. Supriatna, "Kejenuhan Mahasiswa dalam Mengikuti Perkuliahan Daring dan Strategi Penanggulangannya," Edunesia J. Ilm. Pendidik., vol. 2, no. 1, pp. 293-307, 2021.

[9] N. Suryani, "Utilization of digital media to improve the quality and attractiveness of the teaching of history," in The 2nd International Conference On Teacher Training and Education Sebelas Maret University, 2016, vol. 2, no. 1, pp. 131-144.

[10] A. Faridi, "Inovasi pembelajaran bahasa Inggris berbasis ICT dalam rangka meningkatkan mutu pendidikan,” Lembaran Ilmu Kependidikan J. Educ. Res., vol. 38, no. 1, pp. 59-67, 2009.

[11] Kemendikbudristek, Jumlah sekolah berdampak pandemi COVID-19. Jakarta: Kementerian Pendidikan, kebudayaan, Riset dan Teknologi, 2021.

[12] Permendikbud No 65, peraturan menteri pendidikan dan kebudayaan tentang standar proses pendidikan dasar dan menengah. 2013, pp. 1-13.

[13] M. A. T. Al-Maqtri, "How effective is e-learning in teaching English? : A case study," J. Educ. Hum. Dev., vol. 3, no. 2, pp. 647-669, 2014.

[14] S. Ghavifekr, T. Kunjappan, L. Ramasamy, and A. Anthony, "Teaching and learning with ICT tools : Issues and challenges from teachers' perceptions,” Malaysian Online J. Educ. Technol., vol. 4, no. 2, pp. 38-57, 2016.

[15] J. Monica and D. Fitriawati, "Efektivitas penggunaan aplikasi zoom sebagai media pembelajaran online pada mahasiswa saat pandemi Covid-19," J. Communio J. Jur. Ilmu Komun., vol. 9, no. 2, pp. 1630-1640, 2020.

[16] R. N. Laili and M. Nashir, "The use of zoom meeting for distance learning in teaching English to nursing students during Covid-19 pandemic," in UHAMKA International Conference on ELT and CALL (UICELL), 2020, pp. 235-244.

[17] M. S. Ahmadi, "The use of technology in English language learning: A literrature review," Int. J. Res. English Educ., vol. 3, no. 2, pp. 116-125, 2018.

[18] D. Yulistyanti, N. Farkhatin, and D. Mustari, "Penggunaan aplikasi sebagai media e-Learning remaja di Karang Taruna,” J. Empower., vol. 2, no. 1, pp. 89-100, 2021.

[19] L. M. Cakrawati, "Students' perceptions on the use of online learning platforms in EFL classroom," English Lang. Teach. Technol. J., vol. 1, no. 1, pp. 22-30, 2017.

[20] E. Maclellan and R. Soden, "The significance of knowledge in learning: A psychologically informed analysis of students' perceptions," nternational J. Scholarsh. Teach. Learn., vol. 1, no. 1, pp. 1-18, 2007.

[21] H. A. Alfadda and H. S. Mahdi, "Measuring students' use of zoom application in language course based on the technology acceptance model ( TAM )," J. Psycholinguist. Res., pp. 1-18, 2021.

[22] H. Pratama, M. N. A. Azman, G. K. Kassymova, and S. S. Duisenbayeva, "The trend in using online meeting applications for learning during the period of pandemic COVID-19: A literature review," J. Innov. Educ. Cult. Res., vol. 1, no. 2, pp. 58-68, 2020.

[23] M. R. Mubarak, N. Wahdah, A. M. Ilmiani, and H. Hamidah, "Zoom cloud meeting: Media alternatif dalam pembelajaran maharah kalam di tengah wabah Virus Corona (Covid-19),” Arab. J. Bhs. Arab, vol. 4, no. 2, pp. 211-226, 2020.

[24] A. Ramadani and B. Xhaferi, "Teachers' experiences with online teaching using the zoom platform with EFL teachers in high schools in Kumanova," SEEU Rev., vol. 15, no. 1, pp. 142-155, 2020.

[25] S. Suadi, "Students' perceptions of the use of zoom and whatsapp in ELT amidst Covid-19 pandemic," SALEE Study Appl. Linguist. English Educ., vol. 2, no. 1, pp. 51-64, 2021.

[26] R. Vurdien, "Videoconferencing: Developing students' communicative competence," J. Foreign Lang. Educ. Technol., vol. 4, no. 2, pp. 269-298, 2019.

[27] B. Loranc-Paszylk, "Videoconferencing as a tool for developing speaking skills," Second Lang. Learn. Teach., vol. 14, pp. 189-203, 2015. 
[28] T. Wibawanto, "Pemanfaatan video conference dalam pembelajaran tatap muka jarak jauh dalam rangka belajar dari rumah.," J. Teknol. Pendidik., vol. 1, no. 1, pp. 1-9, 2020.

[29] M. R. Ahmadi, "The use of technology in English learning: A literature review," Int. J. Res. English Educ., vol. 3, no. 2, pp. 115-125, 2018.

[30] M. Maryatun, "Efektivitas kegiatan literasi digital dalam meningkatkan kemampuan penulisan karya ilmiah bagi mahasiswa," Fikris J. Ilmu Perpust. dan Inf., vol. 15, no. 2, pp. 145-166, 2020.

[31] S. Menggo, I. M. Suastra, and N. N. Padmadewi, "Self-recording videos to improve academic English-speaking competence," Asian EFL J., vol. 25, no. 5.2, pp. 133-152, 2019.

[32] S. Menggo, "Pembelajaran abad 21," in Seminar Nasional Linguistik dan Linguistik Terapan, 2020, pp. 1-20.

[33] B. Trilling and C. Fadel, 21st century skills: Learning for life in our times. San Francisco: JosseyBass, 2009.

[34] G. Jati, "Perspective on ICT in teaching and learning listening \& speaking in the 21 st century: Beyond classroom wall," J. Teach. Learn. English Multicult. Context., vol. 1, no. 1, pp. 16-29, 2017.

[35] T. Han and F. Keskin, "Using a mobile application ( WhatsApp ) to reduce EFL speaking anxiety," Gist Educ. Learn. Res. J., no. 12, pp. 29-50, 2016.

[36] A. Sherine, A. V. S. Seshagiri, and M. M. Sastry, "Impact of whatsapp interaction on improving L2 speaking skills,” Int. J. Emerg. Technol. Learn., vol. 15, no. 3, pp. 250-259, 2020.

[37] L. Mason, "A critical metaphor analysis of educational technology research in the social studies," Contemp. Issues Technol. Teach. Educ., vol. 18, no. 3, pp. 538-555, 2018.

[38] L. M. Sadiku, "The importance of four skills reading, speaking, writing, listening in a lesson hour," Eur. J. Lang. Lit., vol. 1, no. 1, pp. 29-31, 2015.

[39] H. D. Brown, Language assessment: Principles and classroom practices. New York: Addison Wesly Longman Inc, 2004.

[40] S. Menggo and I. . M. Suastra, "Language use and language attitudes of Sumbawanese speakers in Bali,” Regist. J., vol. 13, no. 2, pp. 333-350, 2020.

[41] N. Guzacheva, "Zoom technology as an effective tool for distance learning in teaching English tomedical students,” Bull. Sci. Pract., vol. 6, no. 5, pp. 457-460, 2020.

[42] A. Anugrahana, "Hambatan, solusi dan harapan: Pembelajaran daring selama masa pandemi COVID19 oleh guru sekolah dasar," Sch. J. Pendidik. dan Kebud., vol. 10, no. 3, pp. 282-289, 2020.

[43] W. Creswell, J, Educational research: Planning, conducting, and evaluating quantitative and qualitative research, Third. New Jersey: Pearson Education, Inc., 2008.

[44] F. Abedini and A. Chalak, "Investigating the inhibitive factors in the speaking of Iranian EFL learners," ournal Appl. Linguist. Lang. Res., vol. 4, no. 6, pp. 82-97, 2017.

[45] M. Aghajani and H. Amanzadeh, "The effect of anxiety on speaking ability: An experimental study on EFL learners,” J. Appl. Linguist. Lang. Res., vol. 4, no. 7, pp. 154-164, 2017.

[46] K. Wu, "The Relationship between language learners' anxiety and learning strategy in the CLT classrooms," Int. Educ. Stud., vol. 3, no. 1, pp. 174-191, 2010.

[47] D. Zhiping and S. Paramasivam, "Anxiety of speaking English in class among international anxiety of speaking English in class among international students in a Malaysian university," Int. J. Educ. Res., vol. 1, no. 11, pp. 1-16, 2013.

[48] O. A. Akinola, "The use of non-verbal communication in the teaching of English language," J. Adv. Linguist., vol. 4, no. 3, pp. 428-433, 2014.

[49] C. P. Zeki, "The importance of non-verbal communication in classroom management," Procedia Soc. Behav. Sci., vol. 1, no. 1, pp. 1443-1449, 2009.

[50] A. Amri, A. Aridah, and W. ParamaIswari, "Study habits and English learning achievement of vocational high school students in Samarinda," Adv. Soc. Sci. Educ. Humanit. Res., vol. 432, pp. 47-51, 2020.

[51] M. A. Cerna and K. Pavliushchenko, "Influence of study habits on academic performance of international college students in Shanghai," High. Educ. Stud., vol. 5, no. 4, pp. 42-55, 2015. 